\title{
Price movement in the Brazilian land market (1994-2010): an analysis in the light of post-Keynesian theory
}

\author{
Evolução dos preços no mercado brasileiro de terras \\ (1994-2010): uma análise à luz da teoria pós-keynesiana
}

TIAGO SANTOS TELLES

ALEX WILHANS ANTONIO PALLUDETO

BASTIAAN PHILIP REYDON*

\begin{abstract}
RESUMO: O presente estudo tem como objetivo avaliar culturas, pastagens e os preços das terras florestais no Brasil, entre 1994 e 2010, à luz da teoria pós-keynesiana. Os resultados fornecem evidência de que a terra, mais do que apenas um simples fator de produção, deve ser concebido como um ativo econômico. Na verdade, o preço da terra rural é determinado não apenas pela rentabilidade esperada decorrente das atividades agrícolas, mas também pelas expectativas dos agentes quanto à sua futura valorização e liquidez em um ambiente econômico permeado de incertezas. Neste contexto, como um objeto de especulação, a terra tem sido particularmente importante como uma reserva de valor.
\end{abstract}

PALAVRAS-CHAVE: preço da terra; pós-keynesiano; economia brasileira.

ABSTRACT: The present study aims to evaluate crop, pasture and forest land prices in Brazil, between 1994 and 2010, in the light of Post-Keynesian theory. The results provide evidence that land, more than just a simple factor of production, must be conceived of as an economic asset. In fact, the price of rural land is determined not only by the expected profitability deriving from agricultural activities but also by the agents' expectations about its future appreciation and liquidity in an economic environment permeated with uncertainty. In this context, as an object of speculation, land has been particularly important as a store of value. KEYWORDS: land prices; post-Keynesian; Brazilian economy.

JEL Classification: E12; G11.

\footnotetext{
* Pesquisador, Instituto Agronômico do Paraná (IAPAR), Londrina, PR - Brasil. E-mail: telles@iapar.br; Doutorando em Ciências Econômicas, Instituto de Economia, Universidade Estadual de Campinas, email: alex.wilhans@gmail.com; Professor Livre Docente, Instituto de Economia, Universidade Estadual de Campinas. e-mail: basrey@eco.unicamp.br. Submetido: 26/fevereiro/2014; Aprovado: 9/outubro/2014.
} 


\section{INTRODUCTION}

Regarding the role that land may - and usually does - play in a capitalist economy, Keynes (1936, p. 218) made a potent observation:

It may be that in certain historic environments the possession of land has been characterised by a high liquidity-premium in the minds of owners of wealth; and since land resembles money in that its elasticities of production and substitution may be very low, it is conceivable that there have been occasions in history in which the desire to hold land has played the same role in keeping up the rate of interest at too high a level which money has played in recent times. It is difficult to trace this influence quantitatively owing to the absence of a forward price for land in terms of itself which is strictly comparable with the rate of interest on a money debt. We have, however, something which has, at times, been closely analogous, in the shape of high rates of interest on mortgages.

Keynes (1936) warns that, given its characteristics, land is not limited to being a mere factor of production, but is an economic asset that is particularly useful to wealth owners due to its ability to function as a store of value.

Thus, alterations in the value of land are not restricted to current or expected changes in production as a result of its use, but are subject to countless other factors that are linked, in the main, to speculation ${ }^{1}$ and to the liquidity of different economic assets. Indeed, through the movement in its price, it is even possible to analyze and quantify important phenomena of a country's economic situation.

In the case of Brazil, it is possible to identify three major periods in respect of the development of land prices, from the second half of the twentieth century until the Plano Real.

The first period runs from the end of the sixties until about 1976, during which time the price of land underwent a sharp increase, mainly due to the modernization of Brazilian agriculture and the large transfer of resources made to the agricultural sector by virtue of the expansion of agricultural credit (Sayad, 1977, 1982; Egler, 1985).

The second period occurs between the mid-seventies and the crisis at the beginning of the eighties, in which prices remained relatively constant (Reydon, 1992). After this period, the price of land in Brazil started to fluctuate sharply, mainly because of the domestic economy's high instability. From 1984 onwards, Brazilian

\footnotetext{
${ }^{1}$ Whenever the word speculation or related terms are used within the present work, they are to be considered as generalization of Kaldor's classical definition (1939, p. 1): "Speculation [...] may be defined as the purchase (or sale) of goods with a view to resale (re-purchase) at a later date, where the motive behind such action is the expectation of a change in the relevant prices relatively to the ruling price and not a gain accruing through their use, or any kind of transformation effected in them, or their transfer between markets".
} 
exports, partially agricultural, increased, which enabled the country's economy to emerge from the deep recession which it had been experiencing (Rezende, 1989). These exports caused changes to economic agents' expectations. Optimism regarding agricultural products, caused by the growth in exports associated with the low returns of the principal liquid assets and the economic agents' mistrust of the government's ability to pay off public debt, increased the demand for land. In 1986, with the Plano Cruzado, a peak in land prices occurred (Rezende, 1989) caused by the government's economic policy, which gave rise to price freezes, real wage increases, sharp decline in the profitability of all financial investments and a rise in investment levels. Furthermore, financing became relatively inexpensive, which was of great importance to the agricultural sector. Consequently, the price of land increased because of the increase in demand for land both as a means of production, proportionate to the growth in demand for agricultural goods, and also as a store of value, in the absence of adequate and safer investment - with the exception of other real estate.

The third period is marked by different policies, general price alterations and changes in expectations, causing abrupt movements in the land market. During the crisis at the end of the eighties, which drastically affected the country's economy, agricultural land prices fell significantly. This process began with the failure of the Plano Cruzado in 1986, a period in which a strong reversal of expectations occurred and which marked an inflexion in the Brazilian land market. The fall in the price of land after the Plano Cruzado was caused by a reduction in aggregate demand and the higher profitability of the financial markets - especially with regard to short-term transactions. The State's need for funding ensured a market for investment in liquid assets in preference to land. In a hyperinflation scenario, it is expected that, in theory, the demand for land should increase. In the Brazilian case, however, by virtue of currency indexation, the increase in demand for land occurred only when there was an increase in insecurity of investments in other liquid asset markets, in the first semester of 1989. At the beginning of 1990, before the adoption of the new plan, when the risk of hyperinflation was even greater, demand for land grew and, consequently, so did its price (Reydon, 1992).

However, with the Plano Collor and the resulting freezing of part of the economy's liquid wealth, a sharp decline was witnessed in the demand for land and, therefore, its liquidity, insofar as it became more costly for owners to convert it to cash without losing value. Thus, transactions involving land became relatively stagnant throughout the second semester of 1990, with prices relatively stable. During the first semester of 1991, however, the value of land again increased. The increase in the economy's overall liquidity, coupled with uncertainty and disbelief regarding the safety of maintaining wealth in any kind of financial investment, caused more funds to be channeled into the land market. Subsequently, however, the price of land in Brazil evidenced a continuous decline until, in December 1992, it reached its lowest level, taking into consideration the period between 1970 and 1992 (Reydon and Plata, 2006).

With the Plano Real's stabilization process, the land market was heavily af- 
fected. The end to high inflation and the immediate economic growth provoked by it, apparent until mid-1994, caused the price of land to rise rapidly. However, with the recession caused by a variety of restrictive policies, especially in relation to credit, particularly for agriculture, from the second semester of 1994, the price of land fell (Reydon and Plata, 2006). After this period, as will be seen later, the land markets took a different path.

In the light of post-Keynesian theory, the present study aims to analyze the development of land prices in Brazil between 1994 and 2010, using data provided by the Gétulio Vargas Foundation (FGVDados).

The paper is organized into four sections, including this introduction. The following section is a discussion of the price drivers in the Brazilian land market. The third section is dedicated to the development of crop, pasture and forest land prices in Brazil from 1994 to 2010. Finally, the last section presents the closing remarks.

\section{PRICE DRIVERS IN THE BRAZILIAN LAND MARKET}

Generally, among the various theoretical currents that have addressed the value of land, such as the classical and neoclassical schools, its price is considered to be the result, either directly or indirectly, of the flow of income that it can earn (Larsen, 1948; Chryst, 1965; Reydon, 1992). In other words, even when starting from different assumptions about the operation of the economy in general, and about the role that land plays within it, it is possible to identify, in terms of the asset's price drivers, a common element among many theoretical approaches that make up the research on the subject: the price of land is determined by the income that it can generate to whosoever uses it. That is to say, ultimately, according to this perspective, the value of land is dictated by its productive capacity ${ }^{2}$.

However, as an economic asset, the price of land is not formed solely by agents' expectations about the profitability derived from its use. The price of land in a particular period is a result of its potential liquidity, among other factors, which may make it a preferred target for speculation (Swierenga, 1970; Brockway, 1983). Thus, the post-Keynesian approach, as we will attempt to demonstrate later, seems more appropriate for land market analysis as it furnishes the necessary theoretical elements to conceive of land as more than a mere factor of production.

The land market must be understood as one in which land title exists, which is capable of being bought and sold by a set of economic agents in monetary terms, or in other words, is capable of being exchanged for money and the trading of which allows for eventual monetary gain - by variations of the combination of the asset's profitability and liquidity (Reydon, 1992; Reydon and Romeiro, 1994). Furthermore, it is important to note that this market can be considered to be quite

\footnotetext{
${ }^{2}$ For further details on the treatment of land prices in other theoretical approaches, see Ortega (1986).
} 
flexible, as agents with different expectations supply and demand land under diverse conditions (Pope and Goodwin Jr., 1984).

According to Davidson (1978), the liquidity of various assets is determined as a function of the time necessary for them to be converted into cash and of their expected capacity to retain value, related to the possibility of the asset being converted into cash without a considerable loss of value. The lower an asset's expected negotiation time and the higher its expected capacity to retain value, the higher its liquidity is considered to be.

For Keynes (1936), a currency's liquidity premium - in other words, the interest rate itself - is the reward for giving up the liquidity that it provides to its holder, or in other words, it is a measure of a wealth owner's desire to preserve wealth in liquid form. Agents hold money to finance their regular transactions because they are speculating about future increases in interest rates, as a precaution against an uncertain future, as currency is a safe asset with which wealth can be maintained over time, or be used for higher volumes of discretionary expenditure, such as for investment (Keynes, 1937).

Keynes's (1936) liquidity preference theory can be generalized for an asset pricing theory, based on the general principle that different degrees of liquidity should be compensated by pecuniary returns that define the rate of return obtained through the possession of different assets, as developed by Reydon (1992) for the land market. Thus, each class of asset has its own interest rate, defined in terms of current market prices, represented by Keynes (1936, p. 206), as:

$$
a+q-c+l
$$

in which $a$ is the asset's expected appreciation rate, $q$ its expected yield (quasirent), $c$ is the expected carrying cost of its conservation (maintenance) and $l$ is the liquidity premium.

In the specific case of the land market, according to Reydon (1992) and Reydon et al. (2014): $q$ is the expected productive yield arising from property; in the case of land, its value depends on expected gains from agricultural production and the possibility of other gains from land ownership, such as those from credit or government subsidies; $c$ is the expected cost of keeping land in an agent's portfolio, that is, all non-productive land costs, such as transaction costs, provision for funding when it is used for land acquisition, taxes and fees resulting from property ownership (Skouras, 1980); $l$ refers to the relative ease of selling the land in the future and depends, therefore, on the expectations formed by the agents in relation to the land market. It is greater to the extent that the economy grows and the demand for capital assets increases, or that there is an increase in demand for liquid assets and that expectations regarding the behavior of other assets are not as promising as those of land. In this approach, preference for liquidity is expressed in the tradeoff between economic returns arising from a particular asset $(a+q-c)$ and the liquidity premium $(l)$, thereby causing substitutions within the structure of demand for assets, liquidity being more prized in proportion to the perception of uncertainty. Thus, in the case of the land market, returns - or the rates of return - 
are compensation for land's lower level of liquidity when compared to currency, which enjoys the highest liquidity premium among economic assets.

Seeking to reduce the discomfort with regard to uncertainty, economic agents adopt practical rules, routines and standards of conduct. These persist over time as long as they enable results considered to be acceptable and the accumulation of information is insufficient to adopt new procedures. This fact provides relative stability to the economic system and allows agents to attempt to predict the decisions of the other agents. Keynes (1936) claims that the agents are based on conventions $^{3}$ so as to coexist with uncertainty.

Indeed, the very nature of capital appreciation reflects decisions about uncertain events, since every capital investment is the result of a comparison between expected returns and the liquidity of diverse assets. It is not immediate, but rather requires an indeterminate amount of time and takes place in a competitive environment.

When an asset is acquired, a decision-making process that compares expected returns and the liquidity of various investment options will have been completed. The choice of asset having been made, it then becomes necessary to make decisions in an effort to meet profitability expectations. The nature of these decisions varies according to the asset and the strategy adopted.

Thus, in a capitalist economy, speculative land use, or in other words, nonproductive use of land merely as a store of value, is an expectations-based form of appreciation of private wealth like any other: when selling land, future returns that compensate its acquisition are expected. In this case, it is expected that the price of the land in the future be such that it ensures its holder gains above or equivalent to those arising from other available investments with similar liquidity.

The real price of land has recorded large fluctuations during Brazil's economic history. To understand these fluctuations, one should keep in mind that the value of land has been influenced by various macroeconomic factors, a fact that suggests a strong interaction between the land market and markets external to agricultural activities, especially the financial markets.

One of the first researchers to systematically study the land market in Brazil was Sayad (1977, 1982). In his analysis of the relationship between the price of land and financial markets, the author takes the Brazilian economy between 1967 and 1973 and maintains that, during this period, land was functioning as a store of value, an important alternative to productive application of capital. He thus dissociated land as a store of value from its function as a production factor, in contradiction of neoclassical theory, as he believed its characteristic as a store of value to be the most important for real estate investment decisions at the time. Accordingly, the price of land would be determined according to its liquidity, since

\footnotetext{
${ }^{3}$ The conventions may be regarded as informal patterns of behavior or thought socially shared. In other words, the conventions are informal institutions. A convention possesses at least two more attributes that other institutions may not have: (a) when consciously observed, a convention is followed, not, or at least, not only because there is external pressure for such; (b) it is, to an extent, arbitrary. For further details, cf. Dequech (2009).
} 
the asset has very low elasticity of supply and substitution. Increases in the price of land would therefore be attributed to speculative demand, linked to its liquidity. Sayad (1977) further highlights the probable reasons that made land the most demanded asset as a store of value in the Brazilian economy. The first comes from a historical perspective, since at that time the Brazilian economy had only recently shed its image as a mainly agricultural nation. The author also notes that the legal and tax systems' form of organization, and that of the financial sector itself - still under development - encouraged the private sector's concentration of wealth on non-financial assets, like land. Furthermore, the right to subsidized credit was also a contributing factor in the rise of rural land prices in Brazil. By enabling a profitable and safe investment for available liquid resources, the author observed that, as long as real estate investments did not fall, it would be very difficult for the financial system to attain better performance in the Brazilian economy. So Sayad (1977) suggested a capital gains tax, arguing that without this intervention it would be difficult for the financial sector to offer an asset profitable enough to compete with those that functioned as stores of value. He emphasized that, at high inflation rates, financial assets could only rival other forms of retention of wealth if they offered adequate protection against the general rise in prices, as was the case of land. Lastly, the author highlighted that the financial sector would have an important task within this process, which would be to change the wealth allocation habits of the private sector in the light of all the previously discussed reasons.

Rangel (2000) is another author who made significant contributions to determining the speculative drivers of land price formation in Brazil. According to the author, trends in land price movements, besides the income component, were associated with the economy's general movements since, according to his theory, the price of land has an inverse relationship with the economy's rates of interest and profit. In this sense, when the economy as a whole shows an upward trend, the price of land falls in proportion to this growth. Since yields from land would remain relatively constant in any phase of the business cycle, during a downturn in economic activity, demand for land would rise. This countercyclical behavior of land prices would lead to expectations of their increase, regardless of the yields it can generate. The author calls this expectation of an asset's appreciation "the fourth rent from land". Thus, the driving element of the variations in the price of land, besides alterations to its yields, would be the economy's average rate of profit. The author also highlights that the growing supply of land due to the advancement of infrastructure and demand for the asset generated by expectations of its gain in value, would also determine the price of land, a phenomenon which demonstrates that elements of a non-agricultural nature have a predominant effect on the behavior of land prices.

According to Reydon (1992), land price movements in Brazil between 1970 and 1991 tracked the general movement of the economy, or in other words, in phases of economic growth, the price of land also rose, contradicting Rangel (2000). Reydon (1992) further highlights that land can be considered an asset that has the characteristics of a store of value and consequently, a privileged object of speculation in periods of high inflation, as was the case of the Brazilian economy in the 
eighties and part of the nineties. This increased the demand for land, causing it to rise sharply in value and making it attractive when compared to other assets, especially in the financial markets. Over time this led many economic agents, in sectors not involved with agricultural production, to acquire land.

In this context, it can be seen that economic instability exacerbates the uncertainties that permeate the management of private wealth. Among the most important consequences are the growth of demand for real estate - generally less vulnerable to devaluation and thus capable of functioning as a store of value - in moments of greater economic turbulence and a decline in demand for these assets in less volatile periods. These fluctuations affect the price of land, which is understood to be an asset which is, simultaneously, productive and financial, inasmuch as it is, at one and the same time, a means of production and a store of value. Thus, given the inflexibility of land supply in the short term, fluctuations in demand for land as a store of value - or, in other words, as a financial asset - could explain an important part of the cyclical fluctuations of real land prices.

Another aspect that influences the price of land is the expansion of infrastructure and logistics services. These structural factors enable the growth of land productivity, which is made possible by the natural fertility of new frontier areas and the incorporation of new technologies. In turn, the increase in land productivity, ceteris paribus, raises the rate of return of investments in land, which contributes to increasing its price.

Subsidized rural credit is another factor that contributes to determining the price of land due to the possibility of it stimulating modernization and increasing agricultural productivity and, consequently, farmers' profitability ${ }^{4}$.

Monetary policy can also decisively affect the price of land. High interest rates may encourage investors, either domestic or foreign, to invest in bonds, reducing pressure upon the land market.

In turn, inflation affects the price of land, in general positively, when it reflects the risk of capital losses, in addition to rendering more uncertain the capitalist calculation of the profitability of the production process.

Reydon et al. (2006) demonstrated, based on an analysis of simulated portfolios that include land, savings and the stock market, that land is an investment with returns comparable to those of these other assets. The study of economic crises from 1980 to 1999 confirmed that an investor whose funds were invested partly in land and partly in savings accounts, during critical periods, would have had better results than if the funds were invested in only one of them. This finding shows that the inclusion of a portion of land together with a portion in savings in an investment portfolio, contributes to reducing investors' losses during periods of stock market crisis.

It is clear, therefore, that the price of land in the Brazilian market can be influ-

\footnotetext{
${ }^{4}$ Causality in the opposite direction should also be noted: to the extent that land is used as collateral in financial contracts for obtaining loans, the higher the price of land, the greater the capability of its holder to obtain credit.
} 
enced by both microeconomic variables (linked to the profitability of farming activities, such as technology, productivity and subsidized rural credit) and macroeconomic variables (linked to the economy's cyclical fluctuations, interest rates, financial markets and expectations regarding inflation). Furthermore, it is worth highlighting speculation, of which land, as has been seen, is an object, evidences yet further the influence of variables associated with the expectations and uncertainties of economic agents.

\section{DEVELOPMENT OF CROP, PASTURE}

\section{AND FOREST LAND PRICES IN BRAZIL}

The development of land prices in Brazil between 1994 and 2010 showed certain instability, it being possible to observe periods of devaluation, stabilization and appreciation of the asset (Figure 1).

Figure 1: Development of (a) crop, (b) pasture and (c) forest land prices in Brazil, from 1994 to 2010 (in thousands of US Dollars).

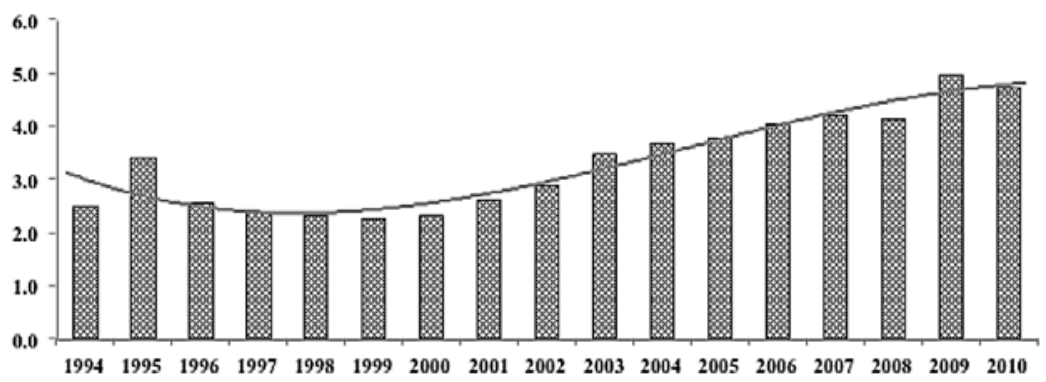

(a)

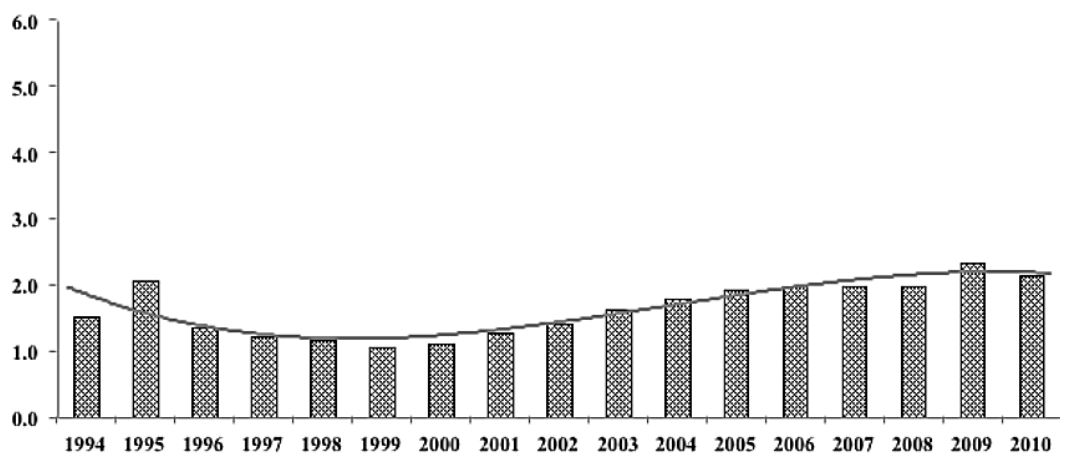

(b) 


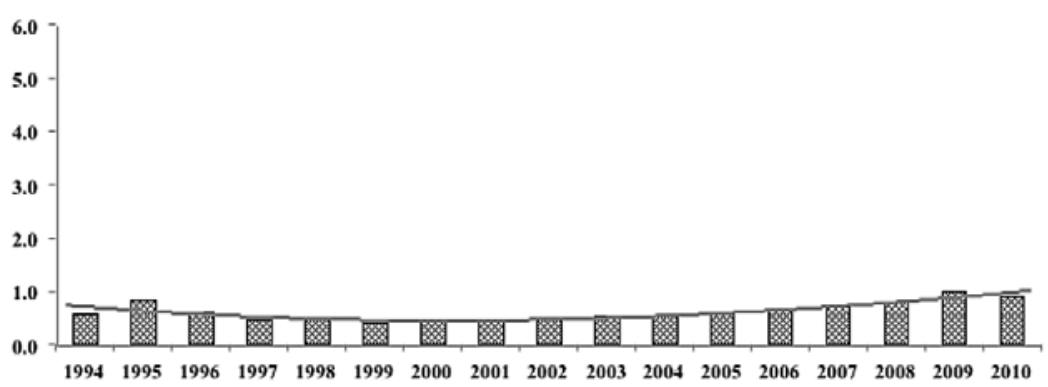

(c)

Source: Prepared by the authors, from data published by FGVDados.

Note: Values in Brazilian Reais adjusted for December 2010 using the IGP-DI price index, and then converted into US Dollars using the same month's average exchange rate.

In 1994, at the beginning of the Plano Real, the high inflation scenario still set the tone for economic agents' behavior. There were even situations in which real interest rates of the Brazilian economy were negative (Garcia and Olivares, 2001). With the currency's low credibility, migration of resources to real assets was stimulated. Thus, between 1994 and 1995, the price of land rose, by virtue of its liquidity $(l)$, as do other assets that function as a store of value: cropland increased in value by $36.74 \%$, pasture land by $34.57 \%$ and forest land by $45.91 \%$ (Figure 1 ). Between 1995 and 1996 however, with monetary stabilization, within a context of appreciation of the currency and high interest rates, prices of real estate assets, such as land, fell. Moreover, with a stronger currency, traditional agricultural commodity exports, such as coffee and soybeans, were penalized, thus affecting the $(q-c)$ component, in respect of the expected economic returns from agriculture. Interest rates, in turn, also on the rise, hurt the entire production sector. It was a time of crisis for agriculture, which was only mitigated by the renegotiation of farmers' debt, which began towards the end of 1996 (Lins and Pinazza, 2004).

Thus, the Plano Real, due to macroeconomic adjustment policies, significantly affected the Brazilian land market and causing, between 1995 and 1996, cropland prices to drop by $25.61 \%$, pasture land prices by $33.97 \%$ and forest land prices by $28.34 \%$. Between 1996 and 1997, this devaluation trend continued, with a 5.89\% drop in cropland prices, a $9.40 \%$ drop in pasture land prices and a $19.96 \%$ drop in forest land prices. Indeed, a large number of producers may have felt under great pressure to sell their land, needing to divest part of their assets in land to invest in new technologies that would ensure greater production efficiency, which may have led to expectations of further devaluation of land in the following years, thereby impacting the $a$ component. Add to this situation the possibility of there being a significant number of landowners disappointed by the asset's low production profitability at the time $(q-c)$, or seeking to sell their land in order to settle outstanding financial commitments. Furthermore, it is possible that investors and business groups made the decision to exit the sector to return to their core businesses, or 
switch to others with greater profitability, which may have affected agents' expectations in terms of the attractiveness of land $(a)$.

The period of decline in the price of land, especially in frontier areas, together with the government's support for agricultural exports, mainly through the Kandir $\mathrm{law}^{5}$ of 1996, given the process of trade liberalization operating since the beginning of the 1990s, enabled the opening of new production hubs. However, the expansion of new farming areas, resulting from technological advancement that enabled the cultivation of cash crops in regions where this was not previously possible, was not accompanied by development in transport infrastructure, thus harming the sector (Telles et al., 2009). Since infrastructure and logistics, as well as proximity to urban centers, influence the price of land, the lack of these elements in these new areas had a negative impact on the value of land due to the increase in agricultural costs $(c)$.

Between 1997 and 1999, the price of land was falling, but at rates lower than those observed between 1995 and 1997. Between 1997 and 1998, cropland prices were devalued by $2.99 \%$, pasture land prices by $6.42 \%$ and forest land prices $4.62 \%$. Between 1998 and 1999, they were devalued by $2.70 \%, 7.32 \%$ and $8.58 \%$, respectively.

Starting in 2000, land prices began to recover. Between 1999 and 2000, cropland prices increased in value by $3.32 \%$, pasture land prices by $4.79 \%$ and forest land prices by $3.59 \%$. This recovery process can be linked to changes in the exchange rate regime that occurred at the beginning of 1999, which caused a drastic devaluation of the national currency, increasing the profitability of the main agricultural commodities $(q-c)$.

This upward trend in land prices continued into subsequent years. Between 2000 and 2001 , cropland prices increased in value by $11.63 \%$, pasture land prices by $14.60 \%$ and forest land prices by $8.71 \%$. Between 2001 and 2002, cropland prices increased in value by $11.30 \%$, pasture land prices by $9.24 \%$ and forest land prices by $7.57 \%$, and between 2002 and 2003 , cropland prices increased in value by $20.25 \%$, pasture land prices by $15.74 \%$ and forest land prices by $2.68 \%$.

The factors that contributed to the increase in the price of land were, in addition to the yields obtained from it as a production factor, an increase in demand for land as a store of value (as already highlighted, a form of investment and hedge against economic instability, that results from its $l$ component). Furthermore, this performance can be partially attributed to farmers' tendencies towards capitalization, seeking to expand their activities, they acquired new areas, and to investors who, in the face of optimistic expectations regarding land appreciation $(a)$ and available liquidity, put upward pressure on prices.

Demand for land intensified in 2003. With an exchange rate favorable to ex-

\footnotetext{
${ }^{5}$ Supplementary law no. 87/1996, known as the Kandir law, came into effect on September 13, 1996, exempting exports of primary and semi-finished manufactured products and imports of machinery and equipment that composed a company's fixed assets from the payment of the ICMS (VAT equivalent). The law provided compensation to states which showed a loss in ICMS revenue due to these exemptions. (Bacha, 2004, p. 173).
} 
ports and the decline and stabilization of real interest rates, investments in land remained buoyant and land prices continued their upward trend.

An additional explanation for the sharp rise in cropland prices in 2003 is associated with 2002's electoral process, in which Luiz Inácio Lula da Silva, the opposition candidate at the time, was elected. According to Novelli (2010), economic agents were fearful of potential alterations to the country's economic policy, a fact that led to the deterioration of macroeconomic conditions (the rise of Brazil's country-risk, inflation, currency devaluation, etc.). Due to the increasing uncertainty and the pursuit of safer investments, i.e., investments whose $l$ component is relatively larger, agents invested resources in the land market, causing prices to rise. However, the government did not change the direction of economic policy.

Between 2003 and 2004, the price of cropland increased by $5.67 \%$, pasture land $10.93 \%$ and forest land $4.91 \%$. With the decline of soybean prices and the collapse of the country's infrastructure and logistics, it was speculation that sustained land values, although at lower rates than in previous years.

In 2005 , new rises in price levels were observed. Cropland prices rose by $2.01 \%$, pasture land by $8.08 \%$ and forest land by $4.83 \%$. This pattern of increasing prices continued in 2006: the value of cropland rose by $7.45 \%$, pasture land by $1.69 \%$ and forest land by $13.02 \%$. Between 2006 and 2007, cropland prices increased by $3.99 \%$, pasture land prices decreased by $1.00 \%$ and forest land prices rose by $5.72 \%$.

It can be seen that between 2000 and 2007, in general, several factors contributed to the rise of land prices in Brazil, particularly those of croplands and pasture lands with regard to the $(q-c)$ component. Initially, as seen above, between 2000 and 2003 the devaluation of the currency had the effect of growing agricultural exports, mainly in the production chains of the soy and meat segments. Then, between 2003 and 2007, even with the unfolding process of currency appreciation, sharp increases in international prices of the main commodities contributed to the stimulation of agriculture. As demand for land also depends on the results obtained from production, good performance influenced prices. Another factor that helped boost the value of land was rural credit. According to Gasques et al. (2008), during this period, the volume of funds allocated to producers and cooperatives increased by $80.4 \%$. In addition, the creation of the Moderfrota ${ }^{6}$ program meant a substantial change in agricultural policy and caused a huge increase in the volume of agricultural machinery and equipment. In this context, the high demand for land from national and international investors contributed greatly to pushing up the price of land.

Between 2007 and 2008 however, cropland prices devalued by $1.20 \%$, while pasture and forest land prices increased in value by $0.85 \%$ and $14.28 \%$ respectively. These results were associated with the global economic scenario, defined by financial crisis, mainly on account of the fall in the price of the main agricultural commodities in the second semester of 2008 . However, indicators might have been

\footnotetext{
${ }^{6}$ Aimed at rural producers and agricultural cooperatives, the program supplied subsidized credit for the acquisition of tractors, harvesters, drapers, sprayers, planters and seeders.
} 
worse but for the bioenergy "fever" and economic agents' pursuit of future gains through land speculation.

With increasing global demand for biofuels, especially from 2008 onwards (Medeiros and Froio, 2012), agricultural markets were buoyant and the prices of products in the international market remained high. This movement expanded the land market due to greater occupation of areas with sugarcane, soybean and corn. Thus, the biofuel sector became a target for a wave of investment and land prices rose. These conditions attracted foreign investors ${ }^{7}$ interested in doing business in agricultural land in the country.

It is worth noting that foreign investors sought land in Brazil both for agricultural production, influenced by the strength of the country's agribusiness sector at the time, and simply because of expectations of the asset's appreciation $(a)$.

Another important economic issue at the time was the subprime crisis, which began in 2006, with more significant impacts in 2008, causing chaos within stock markets around the world. In Brazil, the most immediate effect was the fall in share prices on the stock market, caused by the heavy sales of the stocks of foreign investors, who were anxious to repatriate their capital so as to cover their losses in their countries of origin. Because of this, there was also a sudden and significant rise in the dollar. Subsequently, large Brazilian exporters suffered a drastic credit crunch in the world market in terms of completing business deals with overseas partners. The recession that hit many of the developed countries also affected foreign trade, with the exception of the agricultural sector. Indeed, agricultural credit's low interest rates, mainly government linked, and especially Chinese demand for commodities, benefited agribusiness, as opposed to the relative difficulty faced by other sectors.

Given the economic instability and the significant increase in prices of agricultural commodities, many investors, who were risk-averse and had a greater preference for liquidity $(l)$ may have transferred their resources to land, which is considered to be, according to Gaffney (2009), a smaller risk investiment in times of crisis. There is a tendency in turbulent times to move capital into safer assets, such as land.

Moreover, global demand for food increased, mainly within the so-called emerging economies, particularly China, as mentioned above. This generated increased interest for regions which still had arable land for immediate planting. In this respect, Brazil was the center of attention, by virtue of the abundance of lands yet to be explored (Martinelli et al., 2010).

The sum of these factors led, between 2008 and 2009, to an increase in the value of cropland by $19.92 \%$, of pasture land by $17.10 \%$ and of forest land by

\footnotetext{
${ }^{7}$ According to Sousa (2009), the agricultural frontier on which these investments focused, of low market value and high agricultural potential, was Brazil's central region, called Ma-Pi-To (a confluence of the states of Maranhão, Piauí and Tocantins). According to International Food Policy Research (IFPRI), between 15 and 20 million hectares of land were acquired by groups of foreign investors in poor or developing countries, as is the case of Brazil. The Ministry of Agrarian Development (MDA) reported that, in 2010, more than 4 million hectares of Brazilian land was in the hands of foreign individuals or companies.
} 
$27.67 \%$. However, between 2009 and 2010, after pressure exerted by domestic and foreign investor demand for land, causing a sharp rise in its price, cropland was devalued by $4.77 \%$, pasture land by $7.87 \%$ and forest land by $9.04 \%$.

Between 1994 and 2010, cropland showed a real appreciation of $88.74 \%$, pasture land $40.80 \%$ and forest land $58.32 \%$ (Figure 1 ).

The results of recent years reinforce the theory that land is being used not only for production of food or products linked to bioenergy, but is being kept as a store of value, a finding already made in Brazil, in earlier years, by Sayad (1977, 1982), Egler (1985) and Reydon (1992).

Indeed, all the above elements show that the value of land is linked both to the profitability of agriculture, as observed by Sauer and Leite (2012), and to speculation, especially due to its ability to function as a store of value.

To illustrate the speculative behavior of investors and the use of land as a store of value, Figure 2 shows the development of the price of gold, nominal exchange rates, the Bovespa index and commodity index ${ }^{8}$, between 1995 and 2010.

Figure 2: Movement of (a) the price of gold, (b) nominal exchange rates,

(c) the Bovespa index and (d) the commodity index, in Brazil, from 1995 to 2010

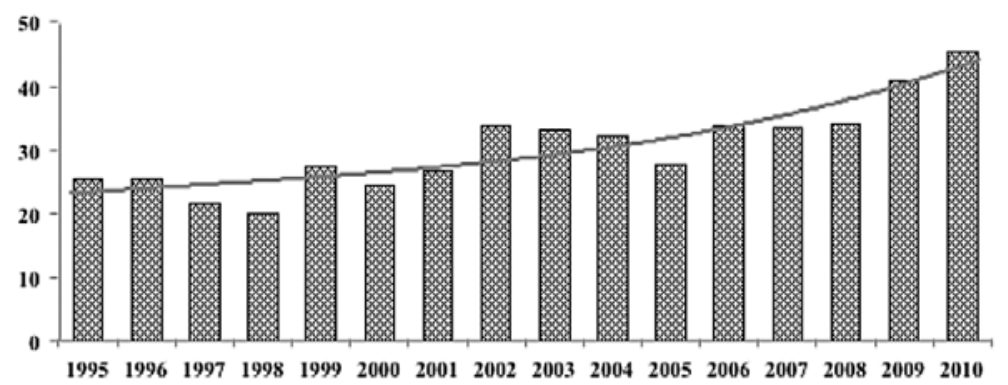

(a) Gold (g) (in US\$)

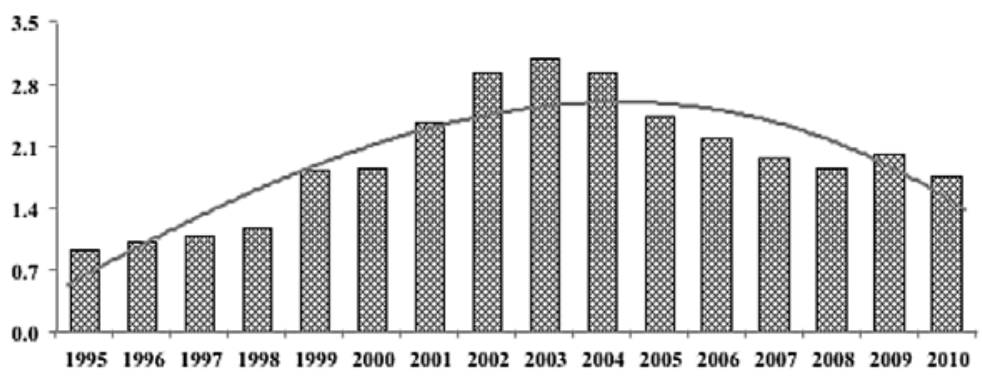

(b) Nominal exchange rate (R\$/US\$)

\footnotetext{
8 The commodity index, calculated by BM\&F BOVESPA, consists of the following products: beef, arabica coffee, corn, soybean and hydrous ethanol.
} 


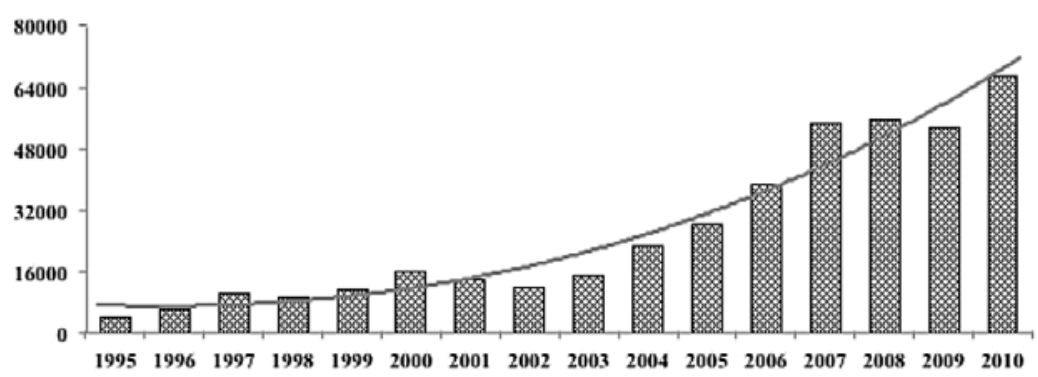

(c) Bovespa index (in points)

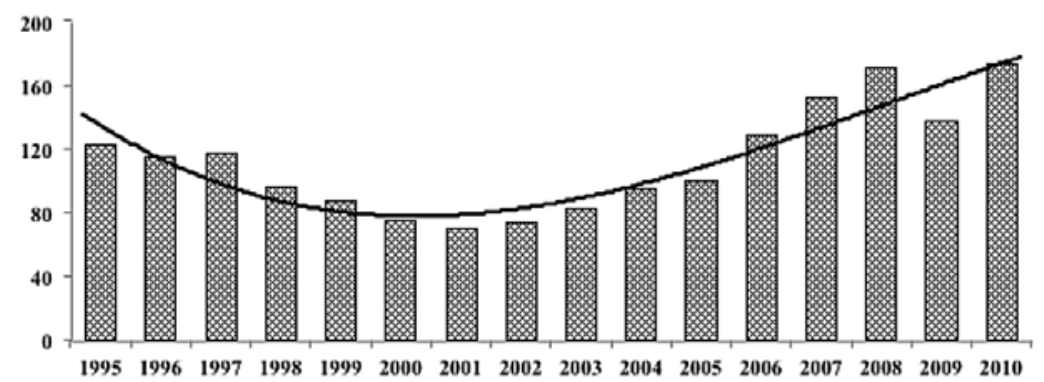

(d) Commodity index (2005 average $=100)$

Source: Prepared based on data from the Central Bank, BM\&F BOVESPA and FGV.

Note: Values in Brazilian Reais inflation-adjusted for December 2010, based on the IGP-DI index, and converted into US Dollars based on the same month's exchange rates.

Between 1995 and 2010, gold increased in value by $79.78 \%$ (Figure 2a), the nominal exchange rate by $91.30 \%$ (Figure 2 b), the Bovespa index by $1610.02 \%$ (Figure $2 \mathrm{c}$ ) and the commodity index by $41.92 \%$ (Figure $2 \mathrm{~d}$ ). Thus, one can see that both factors linked to productive activity, expressed by the assets that make up the commodity index, and those whose movements mainly reflect the speculative behavior of wealth owners, such as gold, the Bovespa index, the US dollar and also, to some extent, the commodity index, negotiated in the form of financial contracts, rose substantially, in line with the movements of the price of land during the same period. Considering the returns ${ }^{9}$ of the abovementioned assets, it is possible to make

\footnotetext{
${ }^{9}$ Returns on the US Dollar and the Bovespa stock exchange, prepared by the Central Bank of Brazil, correspond to the annual average of the percentage variation between prices on the last business day of the reference month and prices on the last business day of the previous month. Similarly, the returns on gold and land were calculated using the percentage variance between the reference month's average price and the previous month's average price for each asset. Note that, although useful for the purposes of this study, this is a very broad measure of returns, since the assets' potential transaction and maintenance/ownership costs are not considered.
} 
a more precise interpretation, suggested here, regarding what drives land prices. Thus, Figure 3 consists of the real returns on gold, the US dollar, the Bovespa index, commodities, croplands, pasture land and forest land between 1996 and 2010.

Figure 3: Development of real returns on investments in (a) gold, (b) US Dollar,

(c) the Bovespa stock exchange, (d) commodities, (e) croplands,

(f) pasture land and (g) forest land in Brazil between 1996 and 2010 (in \%)

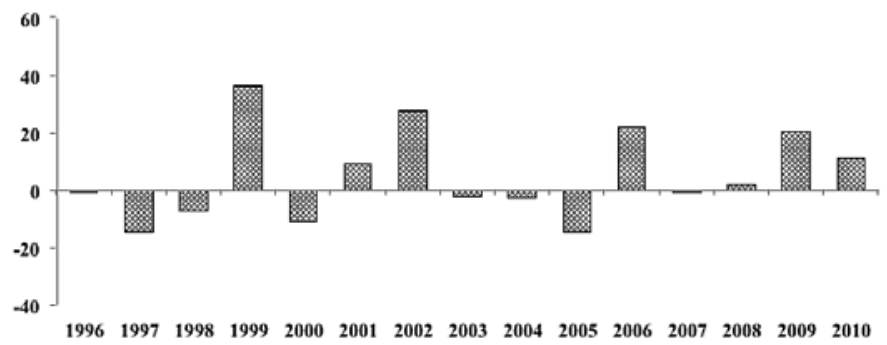

(a) Gold

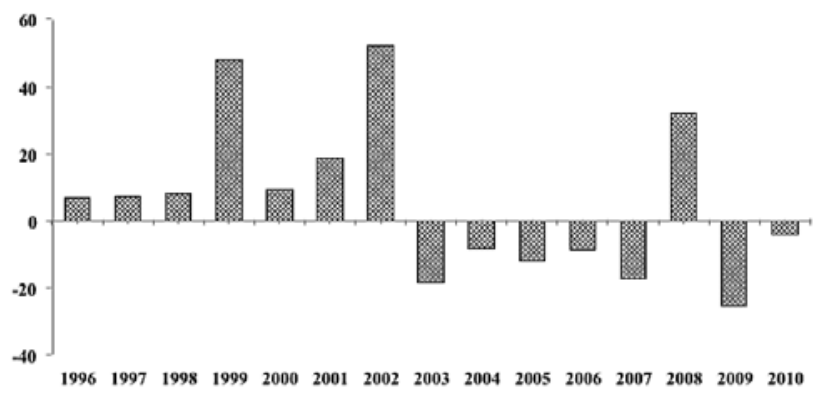

(b) US dollars

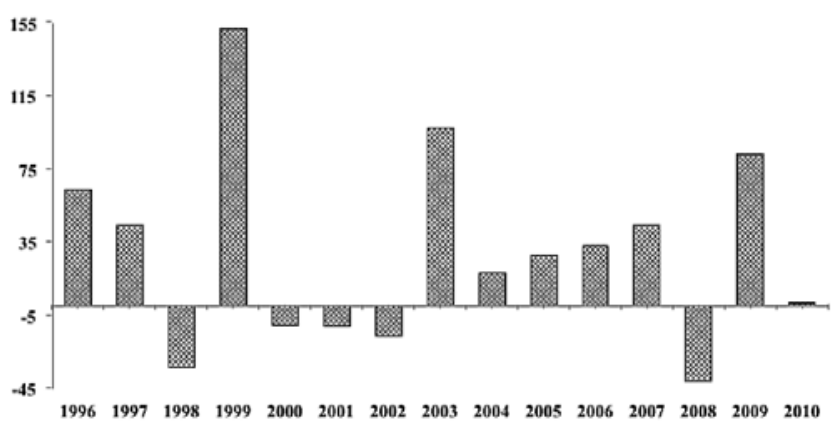

(c) Bovespa index 


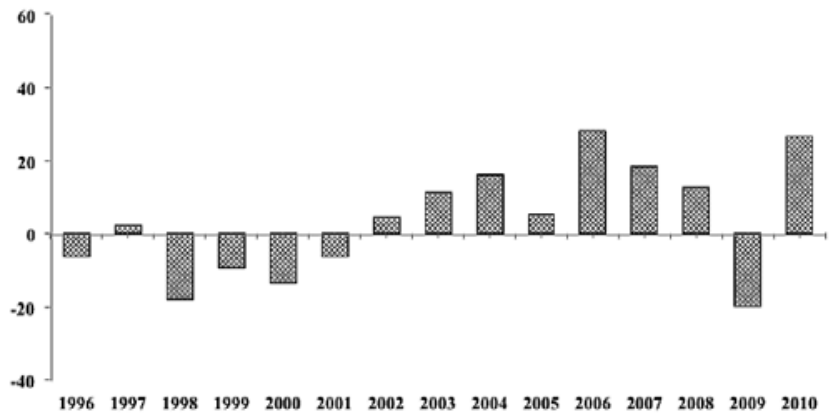

(d) Commodity index

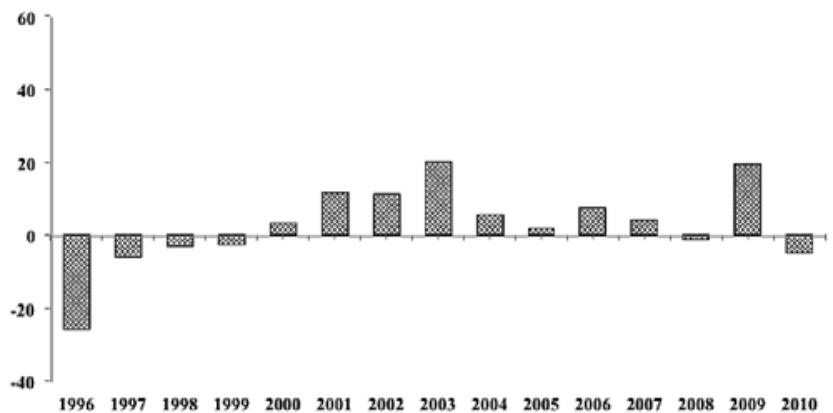

(e) Croplands

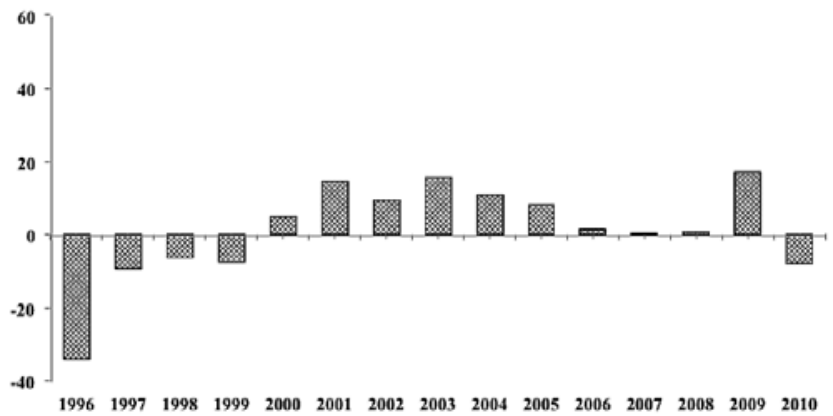

(f) Pasture lands 


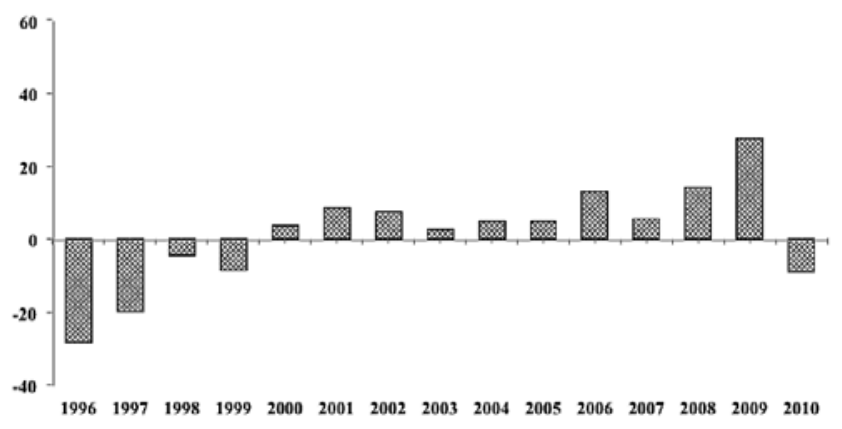

(g) Forest lands

Source: Prepared based on data from the Central Bank of Brazil, BM\&F BOVESPA and FGV.

Figure 3 shows that returns on land, especially cropland (Figure 3e) and forest land (Figure 3g), follow a trend similar to that of returns on gold (Figure 3a) and to the commodity index (Figure 3d). Indeed, even though the creation of more precise measures regarding the movements of these indicators is not possible due to the limitations imposed by the lack of availability of data, it must be recognized that real returns on the three land types, and on the other assets analyzed, depict reasonably similar trends, based on the correlation found between them shown in Table 1 .

\begin{tabular}{|c|c|c|c|c|}
\hline & Gold & US Dollar & Bovespa & Commodities* $^{*}$ \\
\hline Croplands & 0.244 & -0.234 & 0.046 & 0.225 \\
\hline Pasture lands & 0.102 & -0.203 & -0.103 & 0.293 \\
\hline Forest lands & 0.277 & -0.197 & -0.186 & 0.521 \\
\hline
\end{tabular}

Source: Prepared based on data from the Central Bank of Brazil, BM\&F BOVESPA and FGV.

* Unlike the other variables, in this case, the calculation made was of the correlation between returns on land in the reference year and returns on commodities in the previous year.

Although the values are relatively low, mainly because of the sample's short time span, the trend is reasonably clear and confirms the hypothesis suggested here. The development of returns on land, being positively associated with the returns on gold and the commodity index, suggests that the analyzed assets share the same driving factors; investments in both are motivated by their having similar characteristics, as assets, in the view of the economic agents. In other words land must, to some extent, possess attributes similar to those that led wealth owners to invest in gold and commodities, a fact that is ultimately explained by the movements of prices and returns, as observed in Figures 2 and 3. Since commodities are produced as a result of land use, it is natural to expect that an increase in their prices would 
cause the price of land to rise, and that the opposite movement in commodity prices would point to a fall in land prices.

If, on the one hand, the association between trends in land returns and in the commodity index expresses profitability linked to the productive use of land, on the other hand the corresponding movements of returns on land and on gold reveal land's high liquidity and, consequently, its ability to function as a hedge against uncertainty perceived by wealth owners, traits historically recognized as being attributes of gold ${ }^{10}$. Indeed, by showing similar trends, the returns on gold and on land show that both are, under particular circumstances, used as stores of value, a safe haven during periods of greater instability.

Furthermore, the observation that returns on land and returns on the US Dollar and the Bovespa index are negatively correlated, is also quite revealing. If we consider that investments in US Dollars and/or the Bovespa stock exchange are relatively riskier than those in land - a point which does not seem to be disputed - the results shown in Table 1 are easy to interpret. During moments of less uncertainty perceived by agents, and at the same time a greater willingness to invest in riskier assets, wealth owners would be inclined to part with assets that function as a store of value, such as land, and invest in those that offer greater expected profitability, even if they carry greater risk. In this context, agents would tend to build up their portfolios with a higher proportion of US Dollars and Bovespa shares than land. On the other hand, the opposite movement would occur in scenarios of greater instability, in which assets with greater liquidity, such as land, which fulfill the function of a store of value, would be preferable.

These characteristics, in the light of post-Keynesian theory, suggest that economic agents build up their investment portfolios seeking to reconcile safety, profitability and liquidity. Thus, investors' strategies in the land market are driven by the combination of profitability and liquidity, expressed by $a+q-c+l$, taking advantage of the fact that land can function, in many circumstances, as a store of value.

\section{CLOSING REMARKS}

In addition to being a historically important production factor, land is used as a store of value, which affords it special attractiveness for investors, particularly those who speculate in the land market.

Indeed, speculation has been evident in the development of rural land prices in Brazil in recent times. The market, from the beginning of the Plano Real in 1994 up to 2010 , increased in value by approximately $88.74 \%$ for croplands, $40.80 \%$ for pasture lands and $58.32 \%$ for forest lands. Thus, regardless of production gains

${ }^{10}$ About the role of gold as a store of value, see Harmston (1998) and Baur and McDermott (2010). 
or losses, investments in rural land reveal the speculative nature that guided them, due to their function as a store of value.

Speculation has played a major role in exacerbating Brazil's agrarian issue which, since colonial times, has been an obstacle to a more inclusive economic development. Since speculation is a constitutive feature of the capitalist economy - to a greater or lesser extent for different assets - land policies should be aimed at regulating this type of behavior in this market, instead of trying to restrain or prevent it. It is the State's job to regulate it, so it does not cause damage to society as a whole.

In this sense, post-Keynesian theory, addressing both the drivers of land prices as well as the factors that influence their development, plays a crucial role in understanding the speculative behavior of economic agents in this market that other theoretical approaches are perhaps unable to grasp.

\section{REFERENCES}

Bacha, C.J.C. (2004) Economia e Política Agrícola NO Brasil. São Paulo: Atlas.

Baur, D.G.; T.K.Mcdermott (2010) "Is gold a safe haven? International evidence". Journal of Banking \& Finance, v. 34, n. 8, p. 1886-1898.

Brockway, G.P. (1983) “On speculation: a footnote to Keynes”. Journal of Post Keynesian Economics, v. 5 , n. 4 , p. 515-522.

Chryst, W.E. (1965) “Land values and agricultural income: A paradox?” Journal of Farm Economics, v. 47 , n. 5 , p. $1265-1273$.

Dequech, D. (2009) "Institutions, social norms, and decision-theoretic norms". Journal of Economic Behaviour \& Organization, v. 72, p. 70-78.

Davidson, P. (1978) "Why money matters: Lessons from a half-century of monetary theory". Journal of Post Keynesian Economics, v. 1, n. 1, p. 46-70.

Egler, C.A. (1985) "Preço da terra, taxa de juro e acumulação financeira no Brasil”. Revista de Economia Política, v. 5, n. 1, p. 112-135.

Gaffney, M. (2009) "The role of land markets in economic crises". The American Journal of Economics and Sociology, v. 68, n. 4, p. 855-888.

Garcia, M.; G. Olivares (2001) "O prêmio de risco da taxa de câmbio no Brasil durante o Plano Real”. Revista Brasileira de Economia, v. 55, n. 2, p. 151-182.

Gasques, J.G.; E. T. Bastos; M.R.P.Bacchi (2008).”Produtividade e fontes de crescimento da agricultura brasileira" In J. A. de Negri; L.C. Kubota (eds.) Políticas de Incentivo à Inovação Tecnológica. Brasília: IPEA, p. 435-459.

Harmston, S. (1998) "Gold as store of value". Research Study/World Gold Council, n. 22, p. 1-64.

Kaldor, N. (1939) "Speculation and economic stability". The Review of Economic Studies, v. 7, n. 1, p. $1-27$.

Keynes, J.M. (2008[1936]) The General Theory of Employment, Interest and Money. New Delhi: Atlantic.

Keynes, J.M. (1937) "The "Ex-Ante" theory of the rate of interest". The Economic Journal, v. 47, n. 188, p. 663-669.

Larsen, H.C. (1948) "Relationship of land values to warranted values, 1910-1948”. Journal of Farm Economics, v. 30, n. 3, p. 579-588.

Lins, M.A.T.; L.A.Pinazza (2004) “Terra: para produzir, e não para specular”. Agroanalysis, v. 24, n. 7, p. $44-45$.

Martinelli, L.A.;R. Naylor; P. Vitousek; P. Moutinho (2010) “Agriculture in Brazil: impacts, costs, and 
opportunities for a sustainable future”. Current Opinion in Environmental Sustainability, v. 2, n. 5-6, p. 431-438.

Medeiros, M.A.; L. Froio (2012_ "Actors, interests and strategies of Brazilian foreign policy on biofuels". Brazilian Political Science Review, v. 6, n. 1, p. 37-52.

Novelli, J.M.N. (2010) "A questão da continuidade da política macroeconômica entre o governo Cardoso e Lula (1995-2006)". Revista de Sociologia e Política, v. 18, n. 36, p. 227-240.

Ortega, C.V. (1986) "Una revisión de los modelos sobre el mercado y los precios de la tierra en la literatura económica". Agricultura y Sociedad, n. 41, p. 209-254.

Pope, C.A., III; H.L.Goodwin Jr. (1984) "Impacts of consumptive demand on rural land values". American Journal of Agricultural Economics, v. 66, n. 5, p. 750-754.

Rezende, G.C. (1989) “Agricultura e ajuste externo no Brasil: novas considerações”. Pesquisa e Planejamento Econômico, v. 19, n. 3, p. 553-578.

Rangel, I. (2000) Questão Agrária, Industrialização e Crise Urbana no Brasil. Porto Alegre: Editora da UFRGS.

Reydon, B.P. (1992) “Mercado de terras agrícolas e determinante de seus preços no Brasil”. Tese de Doutorado (Doutorado em Economia) - Instituto de Economia da Universidade Estadual de Campinas, Campinas.

Reydon, B.P.; E. S. Añaña; G.O.Kloeckner; F.N.M. Cornelio (2006) "Ativo terra agrícola em carteiras de investimento". In:B.P.Reydon and F.N.M.Cornélio (ed.). Mercados de Terras no Brasil: Estrutura e Dinâmica. Brasília: NEAD, p. 181-206. (Nead Debate, 7).

Reydon, B.P.; L.E.A. Plata (2006) "O plano real e o mercado de terras no Brasil: lições para a democratização do acesso à terra”. In B.P.Reydon and F.N.M. Cornélio. (ed.) Mercados de Terras no Brasil: Estrutura e Dinâmica. Brasília: NEAD, p. 267-284. (Nead Debate, 7).

Reydon, B.P.; L.E.A.Plata; G.Sparovek; R.G.B.Goldszmidt; T.S.Telles (2014) "Determination and forecast of agricultural land prices”. Nova Economia, v. 24, n. 2, p. 389-408.

Reydon, B.P.; A. Romeiro (1994) O Mercado de Terras. Brasília: IPEA.

Sauer, S.; S.P.Leite (2012) "Agrarian structure, foreign investment in land, and land prices in Brazil". The Journal of Peasant Studies, v. 39 (3-4), p. 873-898.

Sousa, A.F. (2009) "Investimento fundiário: terra gera alta rentabilidade”. Agroanalysis, v. 29, n. 12, p. 18-19.

Sayad, J. (1977) "Preço da terra e mercados financeiros" Pesquisa e Planejamento Econômico, v. 7, n. 3, p. 623-662.

Sayad, J. (1982) "Especulação em terras rurais, efeitos sobre a produção agrícola e o novo ITR". Pesquisa e Planejamento Econômico, v. 12, n. 1, p. 87-108.

Skouras, A. (1980) "Land and its taxation as issues in economic theory: what is the reason for their eclipse?" American Journal of Economics and Sociology, v. 39, n. 4, p. 373-382.

Swierenga, R.P. (1970) "Land speculation and frontier tax assessments". Agricultural History, v. 44, n. 3, p. 253-266.

Telles T.S.; M.F.Guimarães; A.C.Roessing (2009) "A infra-estrutura de transporte frente à expansão da cultura da soja no Brasil”. Semina: CiênciasAgrárias, v. 30, suplemento 1, p. 1109-1122. 